\title{
PELAYANAN GEREJA TERHADAP KAUM LANSIA DI MASA PANDEMI COVID-19 DITINJAU DARI IBRANI 10:25
}

\author{
Sumiran Winarto', Bartholomeus Diaz Nainggolan², \\ Stimson Hutagalung ${ }^{3}$, Rolyana Ferinia ${ }^{4}$ \\ Fakultas Filsafat Pasca Sarjana Universitas Advent Indonesia' ${ }^{123}$ \\ Fakultas Ekonomi Universitas Advent Indonesia ${ }^{4}$ \\ sumiranwinarto77@gmail.com
}

\begin{abstract}
The purpose of this study was to explain the extent of the physical condition (eyes and ears) of the elderly, the ability to understand technology, and understanding of online worship towards online worship during the Covid-19 pandemic. The research method used is descriptive quantitative to see the elderly's understanding of online worship, technology, and their health conditions. Questionnaires and interviews were conducted with 50 elderly in the Seventh Day Adventist Magetan and Poncol churches, East Java. The results showed that the elderly had difficulty participating in online worship because their eyesight and hearing had decreased, they did not have a smartphone, and could not run their smartphone for worship. They are more likely to expect services at home and to be served through pastor dan elders visitation.
\end{abstract}

Keywords: elderly, visitation, worship at home, covid-19 pandemic, Hebrew 10:25

\begin{abstract}
Abstrak. Tujuan penelitian ini adalah untuk menjelaskan sejauh mana kondisi fisik (mata dan telinga) lansia, kemampuan memahami teknologi, dan pemahaman ibadah online terhadap kebaktian online di masa pandemi covid-19. Metode penelitian yang digunakan adalah deskriptif kuantitatif untuk melihat pemahaman lansia terhadap peribadatan online, teknologi, dan kondisi kesehatannya. Kuesioner dan wawancara dilakukan kepada 50 lansia di gereja Gereja Masehi Advent Hari Ketujuh Magetan dan Poncol, Jawa Timur. Hasil penelitian adalah lansia mengalami kesulitan mengikuti ibadah online karena penglihatan dan pendengarannya yang sudah menurun, tidak memiliki smartphone, dan tidak dapat menjalankan smartphone untuk berbakti. Mereka lebih mengharapkan kebaktian di rumah dan dilayani melalui perlawatan.
\end{abstract}

Kata kunci: lanjut usia, perlawatan, ibadah rumah, pandemi covid-19, Ibrani 10:25

Perbaktian gereja di masa pandemi Covid-19 telah mengalami

perubahan. Sebelum pandemi, jemaat pada umumnya berbakti di gereja secara tatap muka, saat ini harus berbakti di rumah melaui ibadah online karena diberlakukannya pembatasan sosial. Pelayanan digitalisasi menjadi metode baru dalam hampir semua kegiatan ibadah gereja (SotoAcosta, 2020) walaupun sebenarnya ibadah secara daring (dalam jaringan) telah ada sebelum pandemi. Beberapa gereja di dunia telah 
menerapkan ibadah seperti ini. Di Nigeria, gereja Pantekosta dan Karismatik memanfaatkan teknologi media baru untuk menyebarkan pesan mereka dan menarik serta memobilisasi keanggotaan di seluruh dunia. Umat Kristen Nigeria di Diaspora juga terhubung ke gereja-gereja tanah air mereka melalui Internet, sementara bentuk-bentuk baru dari praktik dan jaringan keagamaan semakin lazim, mereka telah melakukan peribadatan secara online (Chiluwa, 2012). Bahkan gagasan tentang Gereja Terjaring di era teknologi digital ini sudah ada bukan karena alasan pandemi, tetapi untuk merespon tantangan zaman now (Panamokta, 2018).

Tidak dapat dipungkiri, di masa kini semua orang hidup dan beradaptasi di era industri 4.0, artinya dalam otomatisasi pertukaran informasi, melakukan komunikasi melalui internet, komputer dan komputasi kognitif (Yahya, 2018). Kondisi ini memberikan keuntungan yaitu otomatisasi pekerjaan dan kegiatan. Dari perspektif teologi praktis, digitalisasi juga perlu diantisipasi dan diataptasi dalam konteks ibadah online (Campbell \& Delashmutt, 2014). Ibadah online telah menggantikan peribadatan tatap muka (Pillay, 2020). Dengan demikian ibadah online juga telah meruntuhkan masalah geografis, karena memiliki jangkauan lebih luas. (Bryson et al., 2020). Teknologi telah membuat orang-orang di belahan dunia lain dapat beribadah di mana saja melalui internet. (Tambunan, 2020). Melalui internet orang percaya juga dipanggil bekerja untuk mengubah masyarakat yang lebih luas, mengingat bahwa Tuhan 
peduli seluruh dunia ("Digital religion: Understanding religious practice in new media worlds," 2012).

Bagi generasi muda tentunya mereka lebih senang dengan kebaktian yang dilakukan secara daring. Hal ini semakin dimungkinkan karena teknologi digital terus berkembang, munculnya smartphone, tablet, smart TV, dan berbagai piranti digital lainnya yang jumlahnya bertumbuh dengan pesat. Hal ini sangat mendukung diadakannya ibadah secara daring (Tambunan, 2020). Ibadah online memanfaatkan teknologi live streaming, baik lewat Facebook, Youtube, Zoom, Googlemeet, Instagram, Channel Televisi dan lain sebagainya. Surna menyampaikan data bahwa ada tiga besar sarana yang digunakan adalah media komunikasi ibadah yaitu menonton tayangan ibadah secara live streaming, ibadah dengan dua arah melalui zoom menggunakan kombinasi live streaming dan zoom (Surna \& Suseno, 2020).

Namun demikian ibadah online dengan menggunakan tekhnologi di atas memiliki sisi permasalahan bagi anggota jemaat yang sudah lanjut usia (lansia). Mereka mengalami kesulitan untuk beradaptasi dengan teknologi. Penelitian yang dilakukan oleh Ansari, mengindikasikan bahwa lansia mengalami hambatan intrapersonal, struktural dan fungsional untuk beradaptasi dengan media sosial (Ashari, 2018). Kondisi ini diperburuk dengan pandemi yang melanda dunia yang menganjurkan agar lansia diisolasi untuk mengurangi penularan (Armitage \& Nellums, 2020). 
Menteri Agama juga melarang pergi ke rumah ibadah untuk anakanak dan orang lanjut usia yang rentan tertular penyakit, serta orang dengan sakit bawaan yang berisiko tinggi kena Covid-19. Larangan tersebut tertera dalam Surat Edaran Menteri Agama Nomor 15 tahun 2020 tentang Panduan Penyelenggaraan Kegiatan Keagamaan di Rumah Ibadah Dalam Mewujudkan Masyarakat Produktif dan Aman Covid-19 (Kementerian Agama RI, 2020). Peraturan ini mengakibatkan ruang gerak lansia semakin dibatasi.

Itu sebabnya, perlu untuk memberikan perhatian kepada para lansia supaya mendapatkan pelayanan khusus dari gereja dimasa pandemi. Apa yang harus dilakukan oleh gereja untuk melayani para anggota lansia yang tidak bisa hadir di perbaktian online maupun offline di gereja? Perlawatan oleh gembala, penatua, juga diakon sangatlah penting untuk sebuah pertumbuhan kerohanian para lansia karena disaat yang bersamaan mereka sedang mengalami perubahan degeneratif fisik, psikologis, sosiologis, bahkan kerohanian (Paende, 2019). Grane mengatakan Diaken sering duduk bersama yang terluka dan terpinggirkan (Grane, Mc \& Kevin, 2018).

Dari penjelasan latar belakang masalah dan teori maka tujuan penelitian ini adalah: (1) Menganalisis sejauh mana kondisi penglihatan dan pendengaran mempengaruhi lansia untuk mengikuti kebaktian daring melalui smartphone/laptop di rumahnya; (2) Menganalisis sejauh mana pemahaman terhadap tekhnologi sebagai sarana mengikuti ibadah online; 
(3) Menganalisis sejauh mana pemahaman lansia terhadap ibadah online dan harapan mereka untuk pelayanan di masa pandemi.

\section{METODE}

Penelitian ini menggunakan metode deskriptif kuantitatif dengan menyebarkan kuesioner dan wawancara kepada lima puluh lansia jemaat Gereja Masehi Advent Hari Ketujuh Magetan dan Poncol. Kelimapuluh lansia ini adalah jumlah keseluruh dari lansia (populasi). Wawancara dilakukan secara tatap muka dengan mengikuti protokol kesehatan yang dilakukan pada bulan November-Desember 2020. Skala yang digunakan adalah Likert dengan 5 opsi yaitu Sangat Jelas/Selalu (5), Jelas/Sering (4), Kadang-kadang (3), Tidak jelas/Jarang (2). Tidak dapat/Tidak Pernah (1).

Data diolah menggunakan SPSS versi 23 untuk mendapatkan nilai rata-rata dari masing-masing pertanyaan untuk melihat pemahanan lansia mengenai pelayanan gembala, penatua, dan diaken kepada lansia. Hasil dari perhitungan SPSS versi digunakan untuk dasar analisis kualitatif yang didukung dengan wawancara, observasi, dan dokumentasi foto.

Pertanyaan diajukan menurut daftar pertanyaan yang telah disusun yang dibagi kepada tiga dimensi yaitu kesehatan fisik yang terdiri dari tiga indikator yaitu: (1) Apakah saudara bisa melihat dengan baik ke layar monitor?; (2) Apakah pendengaran saudara baik saat mendengarkan kebaktian?; (3) Apakah saudara sanggup mengikuti ibadah dari awal sampai akhir dengan durasi waktu kurang lebih 3 jam? 
Dimensi kedua yaitu pemahaman teknologi dengan indikator: (1) Apakah saudara memiliki smartphone? (2) Apakah keluarga saudara memiliki smartphone? (3) Apakah saudara paham mengoperasikan smartphone?

Dimensi yang ketiga adalah tentang pemahaman mereka tentang ibadah dengan indikator: (1) Apakah ibadah harus di gereja? (2) Apakah beribadah melalui media sosial dirasakan khusuk? (3) Apakah selama pandemi covid-19 saudara mengikuti ibadah daring? (4) Apakah saudara mudah beradaptasi dengan pengoperasian platform kebaktian seperti google meet dan zoom? (5) Jika tidak bisa beribadah secara daring, apakah saudara beribadah dirumah? (6) Apakah perlawatan gembala atau penatua dijam ibadah dapat menggantikan ibadah di masa pandemi?

\section{HASIL}

Dari hasil penelitian terhadap lima puluh anggota lanjut usia diatas, maka didapatkan keterbatasan-keterbatasan yang menjadi kendala bagi lansia untuk mengikuti ibadah online. Ada tiga dimensi yang menyebabkan para lansia sulit untuk menyesuaikan dengan peribadatan online, yaitu: kesehatan fisik, pemahaman teknologi, pemahaman ibadah online.

\section{Dimensi Pertama: Kesehatan fisik}

Pada dimensi kesehatan fisik ini diteliti daya penglihatan, pendengaran, dan ketahanan diri dalam mengikuti durasi ibadah. Untuk penglihatan, rata-rata kemampuan para lansia untuk menatap monitor 
smartphone melalui mata mereka selama kebaktian hanya 2.98 (Kadangkadang). Artinya, sebagaian besar dari lansia mengalami kesulitan menatap layar monitor.

Kemampuan para lansia untuk mendengar acara kebaktian ratarata 3.24. Artinya para lansia masih bisa mengikuti ibadah meskipun sudah tidak terlalu jelas. Lansia sudah mengalami penurunan pendengaran saat melakukan peribadatan online. Kemampuan para lansia untuk mengikuti acara kebaktian kurang lebih 3 jam rata-rata 5.00. Artinya kualitas perbaktian para lansia optimal.

Dengan demikian keterbatasan penglihatan dan pendengaran adalah kendala bagi mereka untuk mengikuti ibadah online, walaupun sebenarnya secara fisik mereka masih bisa bertahan selama 3 jam untuk mengikuti sebuah ibadah.

Tabel 1. Kondisi penglihatan Lansia Jemaat Magetan dan Poncol

\begin{tabular}{|c|c|c|c|c|c|}
\hline & & Frequency & Percent & Valid Percent & $\begin{array}{l}\text { Cumulative } \\
\text { Percent }\end{array}$ \\
\hline \multirow[t]{5}{*}{ Valid } & 1 & 3 & 6.0 & 6.0 & 6.0 \\
\hline & 2 & 13 & 26.0 & 26.0 & 32.0 \\
\hline & 3 & 16 & 32.0 & 32.0 & 64.0 \\
\hline & 4 & 18 & 36.0 & 36.0 & 100.0 \\
\hline & Total & 50 & 100.0 & 100.0 & \\
\hline
\end{tabular}

Tabel 2. Kondisi Pendengaran Lansia Jemaat Magetan dan Poncol

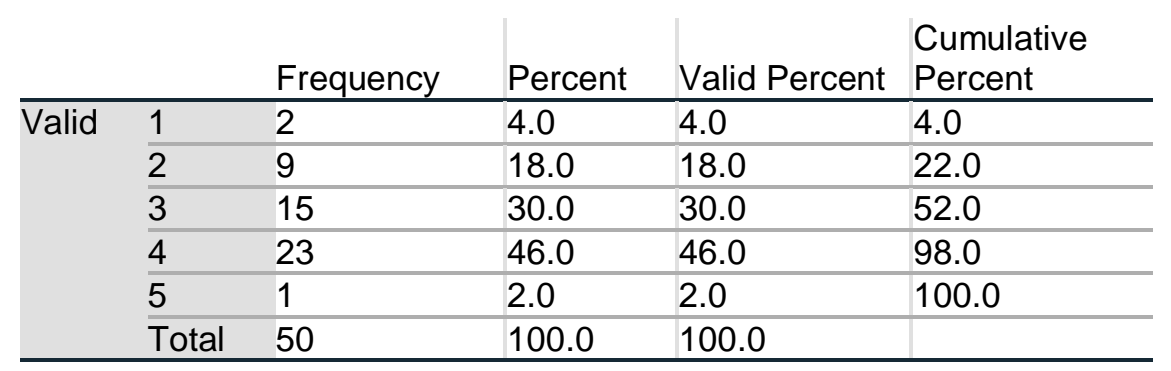


Tabel 3. Kemampuan Lansia Dalam Mengikuti ibadah sampai selesai

\begin{tabular}{|c|c|c|c|c|c|}
\hline & & Frequency & Percent & Valid Percent & $\begin{array}{l}\text { Cumulative } \\
\text { Percent }\end{array}$ \\
\hline Valid & 5 & 50 & 100.0 & 100.0 & 100.0 \\
\hline
\end{tabular}

\section{Dimensi Kedua: Pemahaman Lansia Terhadap Teknologi.}

Rata-rata ada 2.36 lansia yang memiliki smartphone sebagai alat untuk mengikuti kebaktian. Artinya masih ada kurang lebih setengah dari para lansia yang berada di gereja belum memiliki smartphone untuk mengadakan kebaktian daring. Padahal smartphone adalah perangkat yang penting untuk mengadakan kebaktian di zaman sekarang. Tetapi sangat disayangkan, kaum lansia masih ada yang belum memilikinya. Kondisi di atas berhubungan dengan nilai rata-rata lansia yang dapat mengoperasikan smartphone yaitu 2.02. Banyak dari para lansia yang belum melek teknologi. Untuk rata-rata keluarga (anak, cucu, dan keluarga dekat) yang memiliki smartphone adalah sebesar 3.40 sehingga para lansia dapat mengikuti kebaktian melalui smartphone dari keluarganya.

Pemahaman lansia terhadap tekhnologi sebenarnya bisa teratasi oleh keluarga yang memiliki smartphone. Hal ini berbeda dengan lansia yang tidak memiliki keluarga. Tentunya pemahaman tekhnologi juga menjadi keterbatasan lansia untuk mengikuti ibadah online.

Tabel 4. Data Anggota Lansia Yang Memiliki Smartphone

\begin{tabular}{|c|c|c|c|c|c|}
\hline & & Frequency & Percent & $\begin{array}{l}\text { Valid } \\
\text { Percent }\end{array}$ & $\begin{array}{l}\text { Cumulative } \\
\text { Percent }\end{array}$ \\
\hline \multirow[t]{3}{*}{ Valid } & 1 & 33 & 66.0 & 66.0 & 66.0 \\
\hline & 5 & 17 & 34.0 & 34.0 & 100.0 \\
\hline & Total & 50 & 100.0 & 100.0 & \\
\hline
\end{tabular}


Tabel 5. Data Anggota Lansia Yang Tidak Memiliki Smartphone, Namun Anggota Keluarganya Memiliki Smartphone.

\begin{tabular}{llllll} 
& & & & & \\
& & Frequency & Percent & Valid Percent & $\begin{array}{l}\text { Cumulative } \\
\text { Percent }\end{array}$ \\
\hline Valid & 1 & 20 & 40.0 & 40.0 & 40.0 \\
\cline { 2 - 5 } & 5 & 30 & 60.0 & 60.0 & 100.0 \\
\cline { 2 - 5 } & Total & 50 & 100.0 & 100.0 & \\
\hline
\end{tabular}

Tabel 6. Data Lansia Yang Bisa Mengoperasikan Smart Phone

\begin{tabular}{|c|c|c|c|c|c|}
\hline & & Frequency & Percent & Valid Percent & $\begin{array}{l}\text { Cumulative } \\
\text { Percent }\end{array}$ \\
\hline \multirow{6}{*}{ Valid } & 1 & 33 & 66.0 & 66.0 & 66.0 \\
\hline & 2 & 2 & 4.0 & 4.0 & 70.0 \\
\hline & 3 & 5 & 10.0 & 10.0 & 80.0 \\
\hline & 4 & 1 & 2.0 & 2.0 & 82.0 \\
\hline & 5 & 9 & 18.0 & 18.0 & 100.0 \\
\hline & Total & 50 & 100.0 & 100.0 & \\
\hline
\end{tabular}

\section{Dimensi Ketiga: Pemahaman Dan Harapan Lansia Terhadap Ibadah Online}

Konsep ibadah harus di gereja rata-rata lansia yang menyetujuinya adalah 4.26. Sehingga para lansia memiliki pemahaman bahwa beribadah online itu tidak khusuk 2,46 dan hanya rata-rata 1,72 yang mengikuti ibadah online dan mereka sulit untuk beradaptasi dengan ibadah online 2,06. Mereka lebih yakin dengan beribadah sendiri di rumah dan tidak mengikuti program gereja lewat daring sehingga mereka sangat mengharapkan perlawatan ganti kebaktian online dengan rata-rata 4.68 .

Setelah melihat keterbatasan-keterbatasan di atas, maka dapat disimpulkan bahwa para lansia lebih senang untuk mengikuti ibadah offline. Namun karena ibadah tatap muka di gereja belum diperbolehkan, dan jika diperbolehkan ada pembatasan bagi lansia supaya beribadah di rumah. Maka peranan gereja sangatlah dibutuhkan untuk melayani para 
lansia. Mereka mengharapkan para pemimpin gereja memberikan perhatian melalui perlawatan atau kunjungan ke rumah dan mengadakan ibadah di rumah.

Tabel 7. Pemahaman anggota Lansia bahwa Konsep Ibadah Harus Di Gereja

\begin{tabular}{llllll} 
& & Frequency & Percent & $\begin{array}{l}\text { Valid } \\
\text { Percent }\end{array}$ & $\begin{array}{l}\text { Cumulative } \\
\text { Percent }\end{array}$ \\
\hline Valid & 3 & 11 & 22.0 & 22.0 & 22.0 \\
\cline { 2 - 5 } & 4 & 15 & 30.0 & 30.0 & 52.0 \\
& 5 & 24 & 48.0 & 48.0 & 100.0 \\
\hline & Total & 50 & 100.0 & 100.0 & \\
\hline
\end{tabular}

Tabel 8. Pemahaman Anggota Lansia Tentang Kekhusukkan Ibadah Online

\begin{tabular}{llllll} 
& & Frequency & Percent & $\begin{array}{l}\text { Valid } \\
\text { Percent }\end{array}$ & $\begin{array}{l}\text { Cumulative } \\
\text { Percent }\end{array}$ \\
\hline Valid & 1 & 5 & 10.0 & 10.0 & 10.0 \\
\cline { 2 - 5 } & 2 & 23 & 46.0 & 46.0 & 56.0 \\
\cline { 2 - 5 } & 3 & 16 & 32.0 & 32.0 & 88.0 \\
\hline & 4 & 6 & 12.0 & 12.0 & 100.0 \\
\hline
\end{tabular}

Tabel 9. Data Anggota Lansia Yang Lebih Memilih Beribadah Sendiri (Offline) Di Rumah Gantinya Ibadah Online

\begin{tabular}{llllll} 
& & Frequency & Percent & $\begin{array}{l}\text { Valid } \\
\text { Percent }\end{array}$ & $\begin{array}{l}\text { Cumulative } \\
\text { Percent }\end{array}$ \\
\hline Valid & 3 & 8 & 16.0 & 16.0 & 16.0 \\
\cline { 2 - 5 } & 4 & 20 & 40.0 & 40.0 & 56.0 \\
\cline { 2 - 5 } & 22 & 44.0 & 44.0 & 100.0 \\
\cline { 2 - 5 } & Total & 50 & 100.0 & 100.0 & \\
\hline
\end{tabular}

Tabel 10. Data Anggota Lansia Yang Mengharapkan Perlawatan/ Kunjungan sebagai pengganti ibadah online

\begin{tabular}{llllll} 
& & & & Valid & \\
& & Frequency & Percent & Percent & Cumulative Percent \\
\hline Valid & 3 & 1 & 2.0 & 2.0 & 2.0 \\
\cline { 2 - 5 } & 4 & 14 & 28.0 & 28.0 & 30.0 \\
\cline { 2 - 5 } & 35 & 70.0 & 70.0 & 100.0 \\
\cline { 2 - 5 } & Total & 50 & 100.0 & 100.0 & \\
\hline
\end{tabular}




\section{PEMBAHASAN}

Ibrani 10:25 menuliskan bahwa janganlah kita menjauhkan diri dari pertemuan-pertemuan ibadah kita, seperti dibiasakan oleh beberapa orang, tetapi marilah kita saling menasihati, dan semakin giat melakukannya menjelang hari Tuhan yang mendekat adalah prinsip melayani yang penting diterapkan bagi para lansia.

Ibrani 10:25 dibagi menjadi beberapa bagian pembahasan yaitu 1). Menjauhkan diri dari pertemuan ibadah, 2). Dibiasakan oleh beberapa orang, 3). Saling menasihati, 4). Semakin giat melakukannya.

\section{Menjauhkan Diri Dari Pertemuan-Pertemuan Ibadah}

Penulis kitab Ibrani menyatakan supaya jemaat jangan menjauhkan diri dari pertemuan-pertemuan ibadah (Ibr. 10:25), ini berarti ibadah bersama merupakan sesuatu yang penting dilaksanakan oleh orang Kristen (Tambunan, 2020). Kata ibadah dalam bahasa Inggris adalah worship. Dwiraharjo mengutip dari Paul Enns, menyatakan bahwa kata "worship" terdiri dari dua suku kata "worth dan ship" yang artinya melayani "Dia" sebagai Yang Terhormat dan Dihargai. Dengan demikian "ibadah" adalah upaya mengembalikan kehormatan dan penghargaan yang tertinggi kepada Allah (Dwiraharjo, 2020). Marthin Luther menyatakan bahwa dalam ibadah, Tuhan yang pengasih itu berbicara kepada manusia lewat firman-Nya yang kudus, dan kemudian manusia berbicara kepada Tuhan melalui doa dan pujian (White, 2011). Panggilan beribadah bersama adalah perintah Allah yang tertulis di dalam Alkitab. Alkitab 
adalah Firman Allah yang tidak memiliki kesalahan dan otoritas tertinggi dalam kehidupan jemaat bahkan di masa pandemi Covid 19 sekalipun (Surna \& Suseno, 2020).

Perintah Allah supaya kita jangan menjauhkan diri dari pertemuan ibadah ini adalah perintah yang tidak mengenal situasi, termasuk pada saat pandemi, maka gereja harus membuat sebuah metode pelayanan kepada lansia. Tugas yang diemban oleh pimpinan gereja tidaklah gampang. Menurut (Juttah, 2016) salah satu peran mereka adalah menjaga yang sakit dan lemah, membantu orang miskin dan orang tua sambil memberikan pengajaran agar mereka dekat dengan Tuhan.

Dari hasil kuesioner dan wawancara dinyatakan bahwa sebagian besar para lansia mengalami kesulitan menatap layar monitor, pendengarannya tidak maksimal, mereka tidak memiliki smartphone sebagai alat beribadah, bahkan mereka tidak mengerti untuk mengoperasikan alat tersebut, maka ibadah di rumah menjadi solusi penting di masa pandemi sebagaimana jemaat mula-mula (Widjaja et al., 2020). Pelayanan baik online dan offline sangat dibutuhkan bagi lansia. Untuk lansia yang masih memiliki pendengaran yang baik, para penatua bisa mendoakan dan membacakan firman Tuhan melalui telephon, video call.

Namun bagi lansia yang pendengarannya kurang dan penglihatan juga berkurang, maka kunjungan ke rumah dengan menggunakan protokol kesehatan untuk berdoa, memuji dan menyampaikan renungan 
secara singkat akan menjadi berkat bagi mereka. Ibadah bisa divariasikan, namun konten yang harus ada ialah membagikan Firman Tuhan, membaca alkitab, mempelajari doktrin Kristen, berbagi cerita Kristen/kesaksian, bernyanyi, berdoa, memberikan persembahan melakukan percakapan yang saling menguatkan, dan mengaku dosa (Roberto \& J, 2012).

\section{Dibiasakan oleh Beberapa Orang}

John Owen menyatakan, mari kita pertimbangkan satu sama lain; karena Tuhan saat sedang mengumpulkan gereja baik dari orang Yahudi maupun dari orang bukan Yahudi, di antara mereka selalu ada perselisihan yang hebat, sehingga persatuan mereka seperti kombinasi api dan air. Oleh karena itu orang Yahudi mundur dari ini, karena mereka pikir itu adalah penghinaan yang besar bahwa orang bukan Yahudi, harus disamakan dengan mereka dalam kesetaraan sebagai anak-anak yang diadopsi oleh Allah (Owen, 2005)

Itu sebabnya, Jeong (2018) menggambarkan hubungan antara orang Yahudi dan yang bukan Yahudi dengan istilah "tidak-ya-ya". Bangsa Yahudi menjawab dengan "tidak terhadap Injil sedangkan yang non Yahudi menjawab "ya" yang pada akhirnya bangsa Yahudi menjawab "ya" juga. Di situlah objek kecemburuan karena sesuatu yang telah diterima orang bukan Yahudi melalui iman, yaitu, berkat keselamatan.

Jika hal ini diaplikasikan di masa pandemi, maka hal ini juga menimbulkan masalah dalam melayani umat. Pemerintah melalui 
Kementerian Agama melarang warga lanjut usia yang rentan tertular penyakit, untuk tidak datang ke rumah ibadah (Ady, 2020). Dengan demikian mereka tidak boleh dibiarkan begitu saja. Harus ada upaya dari gembala dan penatua untuk mengadakan kunjungan atau pelayanan online secara rutin dan terjadwal bagi mereka. Dengan melakukan program kebaktian secara regular seperti berbakti, berdoa, menyanyi lagu pujian, maka diharapkan para lansia kuat menghadapi pandemi dan bertumbuh dalam iman (Hutagalung \& Ferinia, 2020).

\section{Saling Menasihati}

Kalimat saling menasihati adalah kebutuhan mendasar dalam komunitas orang percaya. Kata "saling menasihati" berasal dari kata $\alpha \lambda \lambda \alpha$, kata yang bermodus imperative untuk menguatkan perintah. Sedangkan паракаһоuvтєS diartikan memanggil datang; mengajak; mengundang; berseru; meminta tolong; memohon; mendesak; menasihati; menghibur; memberi dorongan; berbicara dengan ramah. Penulis surat Ibrani menasihati orang Kristen, agar saling memperhatikan keadaan rohani. Sebagai orang Kristen harus mengajak saudara-saudara seiman supaya mengasihi Kristus dan sesama saudara sebagai landasan agamanya (Tatilu, 2018).

Tugas perlawatan tidak hanya dapat dilakukan oleh gembala jemaat. Anggota jemaat juga perlu dilibatkan dalam perlawatan dan bekerjasama dengan gembala untuk menyampaikan injil kerajaan Allah di tengah-tengah masyarakat untuk menjadi seperti Yesus dan 
memenangkan banyak jiwa (Andrianta et al., 2020). Semakin banyak yang ikut berpartisipasi dalam perlawatan atau kunjungan, maka konsep saling menasihati semakin baik.

Lansia adalah kelompok yang sangat membutuhkan nasihat karena kecenderungan mereka putus asa karena keadaan fisik. Disamping itu pemahaman mereka tentang ibadah harus di gereja adalah permasalahan yang harus mendapatkan nasihat yang sesuai dengan Firman Tuhan. Di dalam Alkitab Perjanjian Baru Yesus menekankan bahwa ibadah itu bukanlah suatu tempat tetapi sebuah partisipasi umat untuk bertemu dengan Tuhan, berbakti, memberitakan injil, dan berbuat kebaikan (Luhukay, 2020). Janji Tuhan mengatakan dalam Matius 18:20 "di mana dua atau tiga orang berkumpul dalam nama-Ku, di situ Aku ada di tengahtengah mereka". Dalam hal inilah maka ibadah menggerakkan umat Tuhan untuk mengalami hubungan spiritual yang erat dengan Tuhan dan kehendak-Nya (Sumarto, 2019).

Jika pemahaman lansia terhadap ibadah online sudah bisa dijelaskan, maka para lansia yang bisa mengoperasikan smartphone atau bergantung kepada keluarga yang memiliki smartphone secara perlahan bisa sesekali mengikuti ibadah online, walaupun kategori seperti ini hanya sedikit. Jika ada anggota lansia tetap tidak mau mengikuti ibadah online dan mau dilayani secara offline, maka ibadah di rumah di mana dua atau tiga orang berkumpul, Allah hadir. Konsep kehadiran Allah di ibadah rumah juga perlu dijelaskan kepada lansia yang memiliki pandangan 
bahwa beribadah harus digereja. Ibadah dirumah merupakan keberlanjutan dari ibadah di gedung gereja, namun dalam skala yang kecil di rumah dengan keluarga (Silitonga, 2020).

\section{Semakin Giat Melakukannya}

Umat Tuhan harus memperhatikan dekatnya masa-masa pencobaan, dan dengan demikian terdorong untuk lebih giat lagi: Dan semakin giat melakukannya menjelang hari Tuhan yang mendekat. Umat Allah harus memperhatikan tanda-tanda zaman, seperti yang sudah dinubuatkan-Nya. Sekarang Rasul Paulus mengajak mereka memperhatikan apa tanda-tanda mendekatnya hari yang mengerikan seperti itu dan memanfaatkannya untuk lebih waspada dan tekun dalam menjalankan kewajiban ibadah (Matthew \& H, 2017). Dalam merujuk kembali pada Advent kedua, penulis buku Ibrani juga meninggalkan kesan dia prihatin bahwa orang percaya sejati mungkin berhenti berharap untuk kedatangan Tuhan dan tergoda untuk menyimpang dari pengakuan iman mereka di dalam Kristus (Morgan, 2020).

Pelayanan kunjungan atau perlawatan kepada anggota lansia adalah pelayanan yang harus dilakukan oleh gembala dan para pemimpin gereja pada saat ini untuk membimbing jemaat kepada pertumbuhan rohani yang baik di masa pandemi (Telaumbanua, 2019). Pada saat kunjungan, tujuannya adalah untuk mengadakan ibadah sederhana dan memberikan kekuatan, semangat, menunjukkan kasih, dan menjalin keakraban (Widiyanto \& Susanto, 2020). 


\section{KESIMPULAN}

Melalui data penelitian dan pembahasan di atas, maka dapat disimpulkan bahwa ada tiga hambatan bagi para lansia untuk mengikuti ibadah online, yaitu: Pertama, hambatan kesehatan fisik dimana penglihatan dan pendengaran telah berkurang. Mereka tidak kuat menatap lama kepada layar. Sehingga apabila kebaktian online berjalan sekitar satu sampai dua jam, maka kemampuan visualnya akan terganggu dan akhirnya mengalami kesulitan berkonsentrasi. Mereka juga tidak mendapatkan siraman rohani yang maksimal karena pendengarannya yang samar.

Kedua, hambatan pemahaman lansia terhadap tekhnologi. Dalam hal ini masih ada lansia yang tidak memiliki smartphone atau perangkat tekhnologi lainnya. Bilamana ada yang memiliki smartphone, mereka terkendala dengan pengoperasiannya. Hanya sedikit lansia yang memiliki smartphone dan bisa mengoperasikan untuk mengikuti ibadah online. Lansia akan bisa mengikuti ibadah online melalui perangkat tekhnologi yang dimiliki oleh keluarganya.

Ketiga, hambatan pemahaman lansia terhadap ibadah online. Selain karena faktor-faktor degeneratif, hal itu juga karena bagi mereka yang menganut faham peribadatan tradisional, perbaktian sesungguhnya adalah jika dilakukan secara fisik (bertemu muka). Di samping itu mereka juga sukar beradaptasi dengan ibadah online Sehingga mereka memilih untuk melakukan ibadah sendiri di rumah. Mereka juga berharap untuk 
dilayani melalui kunjungan gembala atau para penatua untuk beribadah di rumah mereka. Hal ini juga disebabkan ada pembatasan bagi lansia untuk berbakti di rumah ibadah oleh pemerintah.

Untuk itu, maka gereja perlu memberikan pelayanan khusus kepada lansia melalui: (1) Perlawatan atau kunjungan dan mengadakan ibadah di rumah lansia secara teratur dengan mengikuti prosedur kesehatan yang berlaku. Rasul Paulus berkata: "Janganlah kita menjauhkan diri dari pertemuan-pertemuan ibadah kita, seperti dibiasakan oleh beberapa orang, tetapi marilah kita saling menasihati, dan semakin giat melakukannya menjelang hari Tuhan yang mendekat." ( Ibrani 10:25, TB).

Kedua, membantu para lansia untuk dapat melakukan ibadah secara online, terutama membantu penyediaan fasilitas seperti smartphone/laptop, kemudian membantu menjalankannya atau memberitahukan cara untuk menjalankannya, serta ada yang mendampingi pada saat ibadah online berlangsung.

Ketiga, jika kondisi tidak memungkinkan untuk melakukan ibadah online karena jaringan, fasilitas yang tidak ada, maka gembala dan penatua berkewajiban untuk memberikan pengarahan, mengkoordinasikan dan membimbing para lansia untuk mengadakan ibadah dirumah.

\section{DAFTAR PUSTAKA}

Ady, A. (2020). Menag: Rentan Covid-19, Anak-Anak dan Lansia Dilarang 
ke Rumah Ibadah. liputan 6.com.

Andrianta, A., Hutagalung, S., \&, Ferinia, \& R. (2020). Kontekstualisasi Ibadah Penghiburan Pada Tradisi Slametan Orang Meninggal Dalam Budaya Jawa. Visio Dei: Jurnal Teologi Kristen, 2(2), 244-264. https://doi.org/10.35909/visiodei.v2i2.163

Armitage, R., \& Nellums, L. B. (2020). COVID-19 and the consequences of isolating the elderly. The Lancet Public Health, 5(5), e256. https://doi.org/10.1016/S2468-2667(20)30061-X

Ashari, R. G. (2018). Memahami Hambatan dan Cara Lansia Mempelajari Media Sosial. Jurnal IImu Komunikasi, 15(2), 155-170. https://doi.org/10.24002/jik.v15i2.1245

Bryson, J. R., Andres, L., \& Davies, A. (2020). COVID- 19, Virtual Church Services and a New Temporary Geography of Home. Tijdschrift voor economische en sociale geografie, 111(3), 360-372. https://doi.org/10.1111/tesg.12436

Campbell, H. A., \& Delashmutt, M. W. (2014). Studying technology and ecclesiology in online multi-site worship. Journal of Contemporary Religion, 29(2), 267-285. https://doi.org/10.1080/13537903.2014.903662

Chiluwa, I. (2012). Online Religion in Nigeria: The Internet Church and Cyber Miracles. Journal of Asian and African Studies, 47(6), 734-749. https://doi.org/10.1177/0021909611430935

Digital religion: Understanding religious practice in new media worlds. (2012). In H. A. Campbell (Ed.), Digital Religion: Understanding Religious Practice in New Media Worlds. Routledge. https://doi.org/10.4324/9780203084861

Dwiraharjo, S. (2020). Konstruksi Teologis Gereja Digital: Sebuah Refleksi Biblis Ibadah Online di Masa Pandemi Covid-19. EPIGRAPHE: Jurnal Teologi dan Pelayanan Kristiani, 4(1), 1-17. https://doi.org/10.33991/epigraphe.v4i1.145

Grane, Mc \& Kevin, J. (2018). The Deacon as Wise Fool: A Pastoral Persona for the Diaconate. Anglican Theology Review.

Hutagalung, S., \& Ferinia, R. (2020). Menjelajahi Spiritualitas Milenial: Apakah Membaca Alkitab , Berdoa, dan Menghormati Ibadah di Gereja Menurun? Jurnal Teruna Bhakti, 2(2), 97-111.

Jeong, M. (2018). Obedient Gentiles and Jealous Jews: A Fresh Interpretation of Paul's Aim in Romans 11.11-14. Journal for the Study of the New Testament, 41(2), 1-16. https://doi.org/10.1177/0142064X18804434

Juttah, L. J. (2016). The role, identity of deacons and the practice of diaconal ministry in the Anglican Church in Malawi: How is the 
deacon's ministry understood and how does this affect the practice of diaconal ministry in the Anglican Church in Malawi? VID Specialized University.

Kementerian Agama RI. (2020). Panduan Penyelenggaraan Kegiatan Keagamaan di Rumah Ibadah dalam Mewujudkan Masyarakat Produktif dan Aman Covid -19 di Masa Pandemi. Peraturan Menteri Agama Republik Indonesia, 1-4.

Luhukay, A. S. (2020). Analisis Teologis Mengenai Beribadah Di Rumah Di Tengah Pandemi Covid-19 Di Indonesia. Visio Dei: Jurnal Teologi Kristen, 2(1), 43-61. https://doi.org/10.35909/visiodei.v2i1.87

Matthew, \& H. (2017). Tafsiran Ibrani 10:25.

Owen, J. E. (2005). Commentaries On The Epistle Paul The Apostle To The Hebrews By John Calvin. Christian Classics Ethereal Library.

Paende, E. (2019). Pelayanan Terhadap Jemaat Lanjut Usia Sebagai Pengembanggan Pelayanan Kategorial. Missio Ecclesiae, 8(2), 93115.

Panamokta, G. H. (2018). Menuju Gereja Terjaring (Networked Church). Jurnal Teologi, 7(1), 9-30. https://doi.org/10.24071/jt.v7i1.1201

Pillay, J. (2020). COVID-19 Shows the Need to Make Church More Flexible. Transformation, 37(4), 266-275. https://doi.org/10.1177/0265378820963156

Roberto, \& J. (2012). Journal Collection: Family Faith Formation. Fall 2007.

Silitonga, R. (2020). Respon Gereja Atas Pandemik Corona Virus Desease 2019 dan Ibadah Di Rumah. Manna Rafflesia, 6(2), 86-111. https://doi.org/10.38091/man_raf.v6i2.125

Soto-Acosta, P. (2020). COVID-19 Pandemic: Shifting Digital Transformation to a High-Speed Gear. Information Systems Management, 37(4),

https://doi.org/10.1080/10580530.2020.1814461

Sumarto, Y. (2019). Tinjauan Teologis Tentang Ibadah Bagi Pelaksanaan Misi Allah Theological Review of Worship For the implementation of God ' S Mission. Jaffray, 17(1), 57-72. https://doi.org/10.25278/jj.v17i1.312

Surna, S., \& Suseno, A. (2020). Pandangan Teologis Live Streaming Atau Zoom Sebagai Sarana Ibadah Bersama Di Masa Pandemi Covid 19. Jurnal Teologi Praktika, 1(2), 137-152. https://doi.org/10.51465/jtp.v1i2.18

Tambunan, F. (2020). Analisis Dasar Teologi terhadap Pelaksanaan Ibadah Online Pascapandemi Covid-19. EPIGRAPHE: Jurnal Teologi 
dan Pelayanan Kristiani, 4(2), 154-169. https://doi.org/10.33991/epigraphe.v4i2.210

Tatilu, F. O. (2018). Hukum Kasih: Landasan Bersama Agama-agama. Societas Dei: Jurnal Agama dan Masyarakat, 4(2), 219-238. https://doi.org/10.33550/sd.v4i2.73

Telaumbanua, A. (2019). Peran Gembala Sidang Sebagai Pendidik Dalam Pertumbuhan Rohani Jemaat. FIDEl: Jurnal Teologi Sistematika dan Praktika, 2(2), 362-387. https://doi.org/10.34081/fidei.v2i2.45

White, J. F. (2011). Pengantar Ibadah Kristen. BPK Gunung Mulia.

Widiyanto, M. A., \& Susanto, S. (2020). Pengaruh Pelayanan Kunjungan Pastoral Terhadap Pertumbuhan Rohani Jemaat. Evangelikal: Jurnal Teologi Injili dan Pembinaan Warga Jemaat, 4(1), 39-46. https://doi.org/10.46445/ejti.v4i1.214

Widjaja, F. I., Marisi, C. G., Togatorop, T. M. T., \& Hartono, H. (2020). Menstimulasi Praktik Gereja Rumah di tengah Pandemi Covid-19. Kurios (Jurnal Teologi dan Pendidikan Agama Kristen), 6(1), 127139.

Yahya, H. M. (2018). Era Industri 4.0: Tantangan Dan Peluang Perkembangan Pendidikan Kejuruan Indonesia. Universitas Negeri Makasar. 